\title{
Ortaöğretim Öğrencilerinin Problem Çözmeye Yönelik İnançları Ve Akademik Özyeterlilik Algılarının Çeşitli Değişkenlere Göre İncelenmesi
}

\section{Öğretmen Şule Duran ${ }^{1}$ \\ Doc. Dr. Selami Ercan ${ }^{2 *}$}

Geliş tarihi: 02.05 .2020

Kabul tarihi: 01.07.2020

\section{Atıf bilgisi:}

IBAD Sosyal Bilimler Dergisi

Sayı: $8 \quad$ Sayfa: $364-382$

Yıl: 2020 Dönem: Güz

This article was checked by Turnitin. Similarity Index $24 \%$

Bu makalede araştırma ve yayın etiğine uyulmuştur.

1MEB, Ankara, sldrnn@gmail.com ORCID ID 0000-0002-2910-0270

2 Gazi Üniversitesi Gazi Eğitim Fakültesi Ankara Türkiye ercans@gazi.edu.tr ORCID ID 0000-0002-6936-2179

\footnotetext{
* Sorumlu yazar
}

\begin{abstract}
öz
$\mathrm{Bu}$ çalışmada farklı sınıflara devam eden ortaöğretim öğrencilerinin problem çözmeye yönelik inançları ile akademik özyeterlilik algılarının; okul türü, sınıf seviyesi ve cinsiyet parametrelerine göre aralarında kaydadeğer bir ilişkinin olup olmadığının incelenmesidir. Araştırma nicel bir çalışmadır. Çalışmanın evreni iç anadolu bölgesinde ortaöğretime devam öğrencilerden oluşturmaktadır. Verilerin toplanmasıda Kişisel Bilgi Formu, Problem Çözmeye Yönelik İnanç Ölçeği (PCYIÖ), Akademik Öz-Yeterlilik Ölçeği (AÖYÖ) kullanılmıștır. Toplanan verilerin analizinde SPSS istatistik programı ile yapılmıştır. Öğrencilerin problem çözmeye yönelik inançları ile akademik özyeterlilik algıları arasında istatistiksel olarak olumlu yönde orta seviyede kaydadeğer bir ilişki olduğunu göstermektedir. PÇYİ ölçeğinin altboyutu olan matematiksel beceri ve matematiğin yeri ile akademik özyeterlilik inançları arasında istatistiksel olarak düşük seviyede anlamlıdır. PÇYİ ölçeğinin alt boyutları olan problemi anlama, matematiğin önemi ile akademik özyeterlilik inançları arasında istatistiksel olarak orta seviyede kaydadeğer bir ilişki elde edilmiştir. PÇYİÖ'nin problem çözme becerisi alt faktörü ile akademik özyeterlilik inançları arasında istatistiksel olarak kaydadeğer bir ilişkinin olmadığ 1 görülmüştür. Öğrencilerin problem çözmeye yönelik inanç puan ortalamasında fen lisesi öğrencileri lehine istatistiksel olarak kaydadeğer bir farklılık elde edilmiştir. Sınıflar arasında PÇYİ nin altboyutlarında kaydadeğer bir farklılık gözlenmemiştir. Öğrencilerini problem çözmeye yönelik inanç seviyeleri cinsiyete göre erkekler aleyhine istatistiksel olarak kaydadeğer bir farklılık göstermiştir. Okul türlerine göre incelendiğinde öğrencilerin akademik özyeterlilik algısı puan ortalamasında fen lisesi öğrencilerinin diğer lise türlerine göre olumlu yönde istatistiksel olarak kaydadeğer bir farkl1l1k görülmektedir. Öğrencilerinin sınıf seviyesine göre akademik özyeterlilik algısı ortalama puanları yönünden istatistiksel bakımdan kaydadeğer bir farklılık olmadığı neticesine ulaşılmıştır. Öğrencilerinin akademik özyeterlilik algısı yönünden cinsiyete ilgili istatistiksel olarak kaydadeğer bir farklılık göstermemiştir.
\end{abstract}

Anahtar Kelimeler: Problem çözme, Problem çözmeye yönelik inanç, Akademik öz-yeterlilik, Okul türü, Sınıf düzeyi. 


\title{
Investigation of Secondary School Students' Problem Solving Beliefs and Academic Self- Efficacy Perceptions According to Various Variables
}

\author{
Teacher Şule Duran ${ }^{1}$ \\ Assoc. Prof. Dr. Selami Ercan ${ }^{2 *}$
}

First received: 02.05 .2020

Accepted: 01.07.2020

\section{Citation:}

IBAD Journal of Social Sciences

Issue: $8 \quad$ Pages: 364-382

Year: $2020 \quad$ Session: Fall

This article was checked by Turnitin. Similarity Index $24 \%$

1MEB, Turkey, $\quad \underline{\text { sldrnn@gmail.com }}$ ORCID ID 0000-0002-2910-0270

2 Gazi University, Gazi Faculty of Education, Turkey, ercans@gazi.edu.tr ORCID ID 0000-0002-6936-2179

\footnotetext{
* Corresponding Author
}

\begin{abstract}
In this study, the beliefs of secondary school students attending different classes and their self-efficacy perceptions; It is to examine whether there is a significant relationship between school type, class level and gender parameters. Research is a quantitative study. The universe of the study consists of students attending secondary education in the inner Anatolian region. Personal Information Form, Belief Questionnaire for Problem Solving (PSSSS), Academic Self-Efficacy Scale (MMSS) were used to collect the data. In the analysis of the collected data, it was done with the SPSS statistics program. It shows that there is a statistically positive moderate relationship between students' beliefs about problem solving and their perceptions of academic self-efficacy. It is statistically significant at a low level between the mathematical skill, which is the sub-dimension of PSQ scale, and the place of mathematics and academic self-efficacy beliefs. A statistically moderate significant relationship was obtained between understanding the problem, which is the sub-dimensions of PSQ scale, the importance of mathematics and academic self-efficacy beliefs. It was observed that there was no statistically significant relationship between PSQPS's problem solving skill sub-factor and academic selfefficacy beliefs. A statistically significant difference was obtained in favor of science high school students in the belief point average of students for problem solving. No significant difference was observed in the subdimensions of PSQ between classes. Belief levels of students to solve problems showed a statistically significant difference against men by gender. When analyzed by school types, there is a statistically significant difference in the students' academic self-efficacy perception score average compared to other high school types of science high school students. It was concluded that there was no statistically significant difference in terms of academic self-efficacy perception average scores of students according to grade level. There was no statistically significant difference regarding gender in terms of students' academic self-efficacy perception.
\end{abstract}

Key Words: Problem solving, Beliefs about problem solving, Academic Selfefficacy, Gender, Class Level, School Type 


\section{GİRİS}

Eğitim programlarının hedeflerinden birisi karşlaşabileceği problemlerin üstesinden gelebilme ve problemlerini çözebilen bireylerin yetiştirilmesidir (MEB, 2013). Problem tanımı, günlük yaşamda direkt olarak çözüm yolu bulununamayan ancak çözülmesi gereken bir durumdur (Polya, 1962). Problem çözme ne yapılması gerektiğinin bilinemediği hallerde yapılması gerekli olanı bilmek, yalnızca bir doğru sonuç bulma şeklinde algılanmakla birlikte kapsamlı bir çerçeve dahilinde bir zihinsel işlemler ve becerileri kapsayan eylemlerin bütünüdür (Polya, 1945). Problem çözme, kişinin amaç, değer, beceri, ihtiyaç, inanç, alışkanlık ve tutumları ile alakalıdır. Problem çözmenin öğretim aşamasında öğrencilerin sorumluluklarını geliştirme, motivasyonu arttırma, araştırmaya yönlendirme, kalıcı izli öğrenmeyi kazandırma, öğrenmeye ilgilerini arttırma gibi çok sayıda yararı mevcuttur (Chapman, 1997). Problem ve problem çözme süreci her alanda ve öğretimin her safhasında önemli olmuştur. Problem çözme, problem çözme vasıtası ile yeni matematiksel bilgi inşaat etme, matematikte ve diğer alanlarda vuku bulan problemleri çözebilme, poblemleri çözebilmek için uygun olan başka yöntemleri tatbik etmek ve uyarlamak, matematik ile ilgili problemlerin çözmünde takip edilen basamaklarını izlemek ve yansıtmak olarak ifade edilmektedir (NCTM, 2000). Bireyin edindiği deneyimlerin oluşturduğu durumu matematikse problem çözme olarak ifade edilmektedir (Schoenfeld, 1985). Öğrencilerin günlük yaşamda karşılaştıkları sorunlarına çözüm ararken matematiksel problem çözme yöntemlerini kullanmaları yardımcı olmaktadır. Mayer ve Hegarty (1996) problem çözmenin, öğrencilerin matematiksel içerikleri anlamalarına yardımcı olduğundan, matematik öğrenmenin önemli öğelerinden biri haline geldiğini belirtmektedirler.

Eğitim araştırmaları yönünden inançlar kişinin çevresindeki durumlar için geliştirdiği zihnindeki kavrayışlar, temel varsayımlar ve iddialar şeklinde ifade edilmektedir (Richardson, 1996). Matematik ile ilgili inançları, bireyin daha önce yaşamış oldukları deneyimlerinden oluşan bireysel değer yargıları olarak ifade etmektedir (Raymond, 1997). Bu tanımlamaya göre matematiksel problem çözmeye yönelik inancın kişinin mevcut problem ile alakalı biçimde geliştirdiği, zihnindeki mevcut kavrayışlar, ana varsayımlar ve iddialar olduğu söylenebilir. Matematik öğretiminde sadece öğretmenin öğretim yaklaşımı ve öğrencinin başarısı etkili değil aynı zamanda matematiğin doğası, öğretme ve öğrenmeye yönelik inançlarda etkilidir. Bireylerin matematiği öğrenmede matematik hakkındaki inançları pozitif yönde bir yer tutmaktadır (McLeod, 1992). Bireylerin matematik ile ilgili önceki deneyimlerinden sonra varolan bu inançlar, matematik öğrenmeyi pozitif yönde desteklemekle birlikte öğrenme seviyesinin yükselmesine etkisi bulunmaktadır (McLeod ve Mcleod, 2002; Raymond, 1997). Eğitim hayatı süresince oluşan matematik ile ilgili bu inançlar matematik problemi çözme ile ilgili inançlarını ve matematik öğrenme başarısını da olumlu yönde etkilemektedir (Byron, 1995; Kayaaslan, 2006; Schoenfeld, 1989). Bireyin öğrenmelerini ve davranışlarını istenen seviyelere taşımak amacıyla kendi kapasitesine olan inancı özyeterliliktir (Bandura, 1997). Özyeterlilik inançları yüksek olan kişiler, öğrenme süreçlerinde, belirledikleri hedefe yönelik görevlerini planlama, kontrol etme, izleme, kendi çalışma davranışlarını ve kabullendikleri sorumluluğun hepsini uyum içerisinde devam ettirirler (Zimmerman ve Martinez-Pons, 1986). Bireyin problem çözmede kendine değer biçmesi, güvenmesi ve problem çözme konusunda yeterli görmesi; yani özyeterlilik ve özgüven sahibi olması anlamına gelir. Bu yüzden problem çözme becerisi edinebilmek için özyeterlilik inancının yeterli seviyede olması gerektiği söylenebilir.

Özyeterlilik bilinci; bireyin doğrudan kişisel başarısının, gözlemlediği modellerin, sosyal yaşamda inandırma yöntemlerinin (isteklendirme, özendirme) ve psikolojik kaynaklarının (tasa, kabiliyet, öğreti) etmenlerin yardımıyla oluşabilmektedir (Schunk, 2011). Özyeterlilik teorisine dayandırılan akademik özyeterlilik; kişinin akademik bir alanda başarılı olabileceğine yönelik inancıdır (Bandura, 1997). Matematik öğretiminin duyuşsal alanının önemli etkenlerinden birisi özyeterliliktir. Özyeterlilik inanc1, bireylerin matematik başarılarında etkili bir faktör durumundadır (Kiemanesh, Hejazi ve Esfahani, 2004). Matematik özyeterlilik ile matematik başarısı arasında orta seviyede bir ilişkinin olduğu belirtilmektedir (Hackett ve Betz 1989). Duyuşsal özelliklerden özyeterlilik kavramı okulda öğrenme ve başarı faliyetleriyle yakından ilgilidir (Schunk, 2011). Zimmerman (1995) akademik özyeterliğin temel özelliklerini; belirli bir görevi gerçekleştirme yeteneği hakkındaki 
yargılarını kapsamakta, özyeterlilik inancı, farklı alanlarla bağlantılı olup çok boyutludur, özyeterlilik duruma göre bir özellik sergilemekte, özyeterlilik ölçümü performans için saptanan ölçütler temel alınarak ölçülmektedir. Bireylerin akademik yeteneklerine bağlı olarak geliştirmiş oldukları inançları, kendilerinin öğrendiği bilgi ve beceriler ile neler yapabileceklerini fark etmelerine imkan vermektedir (Bıkmaz, 2004). Bireylerin akademik özyeterlilik bilinci ve matematikteki başarıları arasında anlamlı ilişkilerin olduğu gözlenmiştir (Cribari, 2006; House, 2003; Bourquin, 1999). Lise öğrencilerinin bilişsel becerileri kontrol edildiği durumda bile matematiğe yönelik özyeterlilik algıları ve matematik problemlerini çözme başarıları arasında güçlü ve doğrusal bir ilişki olduğu söylemektedir. Özyeterliliğin, öğrencilerin genel akademik başarısını tahmin etme gibi problem çözme başarısını da tahmin etmekte önemli bir rol oynadığ 1 belirtmektedirler (Pajares ve Kranzler, 1995). Özyeterlilik algısının ile matematik başarısının birbirleriyle yüksek düzeyde bir ilişkili olduğunu, kız öğrencilerin kaygı düzeylerinin daha yüksek ve özyeterlilik bilinçlerinin daha düşük düzeyde olmasına karşın erkek öğrencilerin kaygı düzeylerinin daha düşük ve erkek öğrencilerin özyeterlilik bilinçlerinin daha yüksek seveyide olduğunu ifade etmişlerdir (Malpass, O’Neil ve Hocevar 1996). Mason ve Scrivani'e (2004) göre ilköğretim öğrencilerin matematik ve matematik ile ilgili problem çözme hakkındaki inançları ile matematikte ortaya koydukları performansları ve anlamaları arasında belirgin bir şekilde ilişki olduğunu ifade etmektedirler. Kız öğrencilerin özyeterlilik algısının erkek öğrencilerin özyeterlilik algısına nazaran anlamlı düzeyde daha yüksek olduğu fakat yaş değiş̧keni yönünden karşılaştırıldığında anlamlı bir ilişki bulunamadığını ifade etmektedirler (Kumar ve Lal, 2006). Lise 10. Sınıf öğrencileri üzerinde yapılan bir araştırmada problemin okunup cevaplanmasından sonra, probleme dair inançların farklılaştığını ifade etmişlerdir. Bu inançlar, öğrencilerin yeterli bilgi ve beceri sahibi olma durumlarında bile öğrencilerin problem çözümlerindeki başarılarına olumsuz yönde etki ettiğini belirtmişlerdir (Yılmaz , 2007). Problem çözmeye yönelik inanç sistemleri ve yaklaşımları arasında kompleks bir ilişki olduğu üzerine bulgular belirlemişlerdir (Callejo ve Vila, 2009). İnançları ve tutumlarına göre öğrenciler genellikle dört kategoriye ayrılır. Bazı öğrenciler çok çalışır, problem çözme yeteneklerine güvenirler, bazı öğrenciler yanlış cevap vermekten korktukları için öğretmenin ağzından çıkan her şeyi ezberlemeye çalışırlar, bazı öğrenciler matematiği anlayamayacaklarına inandıkları için az çalışırlar, bazı öğrenciler ise matematiğin kendilerine yarar sağlamayacağına inandıkları için az çalışırlar. Birinci grup matematiğe karşı olumlu ve kendine güvenli bir tutum takınmalarını sağlayan uyumlayıcı inançlara sahiptir. Diğer üç grup ise öğrenmeyi gelişen ve eğlenceli bir süreç olarak görmelerine engel olan çeşitli uyumsuz inanç kombinasyonlarına sahiptir. Birçok öğrenci birden fazla kategoriye girdiğini veya içinde bulundukları kategorinin öğretmene veya materyale bağlı olduğunu düşünür (Bassarear, 1997). Lise öğrencilerinin matematik kaygıları bakımından sınıf seviyelerine göre kayda değer bir farkın olmadığını ifade etmektediler (Yenilmez ve Özabac1, 2003). Ortaöğretim öğrencilerinin sınıf seviyesi yükseldikçe, matematik dersi ile ilgili özyeterlilik inanç puanları ile bu derse yönelik tutum puanlarının ortalamasının arttığı ifade etmektedirler. Ayrıca matematik dersin ile ilgili kaygı düzeyleri puan ortalamalarının ise azaldığını ifade etmektedirler (Kurbanoğlu ve Takunyac1, 2012). Sezgin'e (2013) göre, öğrencilerin matematiğe yönelik tutum ile akademik özyeterlilikleri arasında anlamlı bir seviyede ilişki olduğu söylemektedir. Ortaöğretim öğrencilerinin problem çözme becerileri bakımından kız öğrencilerin erkek öğrencilere kıyasla daha iyi olduğu ifade edilmektedir.

Yapılan literatür incelendiğinde ortaöğreyim öğrencilerinin problem çözme inançları ve akademik özyeterlilik arasındaki ilişki durumunun bazı değişkenler bazında incelenmediği gözlenmiştir. Bundan dolayı bu çalışmada, ortaöğretim öğrencilerinin matematiksel problem çözmeye yönelik inançları ve akademik özyeterlilik algısının bazı değişkenler (okul türü, cinsiyet, sınıf düzeyi) arasında kayda değer bir ilişkinin durumunu incelemektir. Bu hedef gözeltilerek;

1. Öğrencilerin matematiksel problem çözmeye yönelik inançları okul türüne göre istatiksel olarak kayda değer bir farklılık oluşturmakta mıdır?

2. Öğrencilerin matematiksel problem çözmeye yönelik inançları sınıf seviyelerine göre istatiksel olarak kayda değer bir farklılık oluşturmakta mıdır? 
3. Öğrencilerin matematiksel problem çözmeye yönelik inançları cinsiyete göre istatiksel olarak kayda değer bir farklılık oluşturmakta mıdır?

4. Öğrencilerin akademik özyeterlik algıları okul tipine göre istatiksel olarak kayda değer bir farklılık oluşturmakta midır?

5. Öğrencilerin akademik özyeterlik algıları sınıf seviyesine göre istatiksel olarak kayda değer bir farklılık oluşturmakta mıdır?

6. Öğrencilerin akademik özyeterlik algıları cinsiyete göre istatiksel olarak kayda değer bir farklılık oluşturmakta mıdır?

7. Öğrencilerin matematiksel problem çözmeye yönelik inançları ve akademik özyeterlik algıları arasında istatiksel olarak kayda değer bir ilişki var mıdır?

sorularına cevap aranacaktır.

\section{YÖNTEM}

\section{Araştırma Modeli}

$\mathrm{Bu}$ çalışmanın amacı matematiksel problem çözmeye yönelik inançlarını "Matematiksel Beceri", "Matematiğin Yeri', "Problemi Anlama", "Matematiğin Önemi” ve 'Problem Çözme Becerisi” ile faktörleri yönünden, akademik özyeterlilik algılarının; okul türü, sınıf düzeyi, cinsiyet değişkenleri bazında incelenmesidir. Bu araştırma sonucunda beş faktörün Cronbach alfa iç tutarlık katsayısı sırasıyla $0.911,0.777,0.720,0.754$ ve 0.765 olarak hesaplanmıştır. Ölçeğin bütünü için bakıldığında Cronbach alfa iç tutarlık katsayısı ise 0.865 olarak hesaplanmıştır. Ayrıca akademik öz yeterlilik ölçeği 33 maddeli ve 5'li likert derecelendirmeye göre $A=1$ 'oldukça az güvenirim' ve $E=5$ 'çok fazla güvenirim' ifadeleri arasında $\mathrm{A}=1, \mathrm{~B}=2, \mathrm{C}=3, \mathrm{D}=4, \mathrm{E}=5$ olacak şekilde değerlendirilmektedir. Bu çalışmada Cronbach Alfa katsayısı ölçeğin tamamı için 0.90 olarak hesaplanmıştır.

\section{Katılımelar}

Bu çalışmanın örneklemi İç Anadolu Bölgesinde bir il merkezinde 2016-2017 Eğitim-Öğretim y1lında öğrenim gören lise birinci ve lise son sınıf öğrencisi toplam 418 kişi oluşturmaktadır. Araştırmaya katılmış olan öğrencilerin cinsiyet, okul ve sınıf seviyelerine göre dağılımarı Tablo 1'de gösterilmektedir.

Tablo 1. Öğrencilerin Demografik Özelliklerine İlişkin Bilgiler

\begin{tabular}{|c|c|c|}
\hline Değişken & $\mathrm{N}$ & $\%$ \\
\hline \multicolumn{3}{|l|}{ Cinsiyet } \\
\hline $\mathrm{K}_{1 \mathrm{z}}$ & 242 & 58 \\
\hline Erkek & 176 & 42 \\
\hline \multicolumn{3}{|l|}{ Okul } \\
\hline Meslek lisesi & 193 & 46 \\
\hline Anadolu lisesi & 138 & 33 \\
\hline Fen Lisesi & 44 & 11 \\
\hline Sosyal bilimler lisesi & 43 & 10 \\
\hline \multicolumn{3}{|l|}{ Sinıf } \\
\hline 9. sinif & 217 & 52 \\
\hline 12. sinif & 201 & 48 \\
\hline
\end{tabular}

Araştırma örneklemi \%58'i (N=242) kız, \%42'si (N=176) erkek olmak üzere toplam 418 öğrenciden oluşmaktadır. Öğrencilerin \% 46'sı (N=193) meslek lisesi'ne, \%33'ü $(\mathrm{N}=138)$ anadolu lisesi'ne, \%11'i $(\mathrm{N}=44)$ fen lisesi'ne, \%10 ( $\mathrm{N}=43)$ sosyal bilimler lisesi'ne devam etmektedir. Öğrencilerin \%52'si ( $N=217)$ 9. sınıfta, \%48'i ( $N=201)$ 12. sınıfta öğrenim görmektedir. Bütün lise türünde haftalık altı saat matematik ders vardır. 


\section{Araştırmada Kullanılan Veri Toplama Araçları}

$\mathrm{Bu}$ araştırmada çalışmaya katılan öğrencilerden problem çözmeye yönelik inançları ve akademik özyeterlilikleri ile ilgili bilgiler toplanmıştır. Katılımcılara Problem çözmeye yönelik inançlarını belirlemek için Matematiksel Problem Çözmeye Yönelik İnanç Ölçeği (Kloosterman \& Stage, 1992, Türkçe'ye uyarlayan, Hacıömeroğlu, 2011b) ve Akademik özyeterlilik inançlarının belirlenmesinde Akademik ÖzYeterlilik Ölçeği (Owen \& Froman, 1988 Türkçe'ye uyarlayan Kemer, 2006) kullanılmıştır. Araştırmacılar tarafından hazırlanmış olan Kişisel Bilgi Formu yardımıyla, katılımcılardan öğrenimlerine devam ettikleri okul, sınıf, cinsiyet durumuna dair bilgiler toplanmıştır. Bu bilgilerin toplanması için gerekli etik izinler alınmıştır. Örneklem uzayında olan ortaöğretim kurumlarının yöneticileri ile görüşüp izin belgelerimiz ibraz edilerek uygun zaman ayarlamaları yapılmıştır. Verileri toplama süresi dört hafta sürmüştür. Matematiksel Problem Çözmeye Yönelik İnanç Ölçeği, Akademik Öz-Yeterlilik Ölçeği ve Kişisel Bilgi Formu aynı zamanda uygulanmıştır.

\section{Matematiksel Problem Çözmeye Yönelik İnanç Ölçeği}

Kloosterman ve Stage (1992) tarafindan oluşturulan Türkçeye de Haciömeroğlu (2011b) tarafindan uyarlanmış olan Matematiksel Problem Çözmeye Yönelik İnanç Ölçeği (PÇYİÖ) kullanılmıştır. Bu ölçeğin açımlayıcı ve doğrulayıcı faktör analizinden elde edilen neticeler, ölçeğin Türkçe formununda "Matematiksel Beceri", "Matematiğin Yeri", "Problemi Anlama", "Matematiğin Önemi" ve 'Problem Çözme Becerisi”' olmak üzere beş faktörden oluşmaktadır. Hacıömeroğlu (2011a) tarafından öğretmen adaylarına uyarlanan ölçek; uzmanlar tarafindan değerlendirilerek kullanılan kelime, kavram ve ifade bakımından lise öğrencilerine uygulanabilir olduğu görüşüne varılmıştır. Kullanılan ölçek için gerekli izinler alınmıştır.

\section{Akademik Öz-Yeterlik Ölçeği (AÖYÖ)}

Owen ve Froman (1988)'ın geliştirdiği ve Türkçe'ye uyarlaması Kemer (2006) tarafından yapılan Akademik Öz-Yeterlik Ölçeği ile çalışmaya katılan öğrencilerin akademik özyeterlilik inançları, belirlenmiştir. Kullanılan ölçek için gerekli izinler alınmıştır.

\section{Kişisel Bilgi Formu}

Araştırmacılar tarafından oluşturulan Kişisel Bilgi Formu yardımıyla, katılımcılardan öğrenim sürdürdükleri okul, sınıf, cinsiyet durumuna ilişkin bilgiler toplanmıştır.

\section{Verilerin Analiz Edilmesi}

Araştırmada elde edilen verilerin çözümlenmesinde Kolmogorov-Smirnov Testi sonucu verilerin normal dağ 1 lım göstermediği belirlenmiş $(\mathrm{p}=.000)$ ve nonparametrik testlerden Spearman Korelasyon, Mann Whitney U, Kruskal Wallis teknikleri kullanılmıştır. İstatistiksel çözümleme işlemlerinin tamamında bir istatistik analiz paket programı uygulanmıştır.

\section{BULGULAR}

$\mathrm{Bu}$ araştırmada, öncelikle problem çözmeye yönelik inanç ölçeği ile akademik özyeterlilik ölçeğinden elde edilen veriler değerlendirilip aralarındaki ilişki incelenmiştir. Daha sonra öğrencilerin problem çözmeye yönelik inançlarının demografik verilere göre farklılaşması incelenmiştir.

Analizlere geçilmeden önce problem çözmeye yönelik inanç ve alt faktörleri ile akademik özyeterlilik dağılımlarını incelemek amacıyla Kolmogorov-Smirnov Testi yapılmıştır. Bunun sonucu aşă̆ıdaki tabloda gösterilmiştir. 
Tablo 2. Problem Çözmeye Yönelik Inanç ve Alt Faktörleri Puanları ile Akademik Öz-Yeterlik Puanları Kolmogorov-Smirnov Testi

\begin{tabular}{lrrr}
\hline Faktörler & İstatistik & Serbestlik Derecesi & $\mathrm{p}$ \\
\hline Problem çözme &, 067 & 418 &, 000 \\
\hline Matematiksel beceri &, 140 & 418 &, 000 \\
\hline Matematiğin yeri &, 107 & 418 &, 000 \\
\hline Problemi anlama &, 087 & 418 &, 000 \\
\hline Matematiğin önemi &, 116 & 418 &, 000 \\
\hline Problem çözme becerisi &, 121 & 418 &, 000 \\
\hline Akademik öz yeterlik &, 049 & 418 &, 017 \\
\hline
\end{tabular}

Kolmogorov-Smirnov Testine göre $\mathrm{p}<.05$ olduğu için problem çözmeye yönelik inanç ve alt faktörleri ile akademik özyeterlilik dağılımları normal değildir. Dağılıma ilişkin analiz sonuçlarına göre; öğrencilerin problem çözmeye yönelik inançları ile akademik özyeterlilik arasındaki ilişkilerin incelenmesinde Spearman Korelasyon analizi kullanılırken, öğrencilerin problem çözmeye yönelik inanç ve alt faktörleri ile akademik özyeterliliklerinin okul türüne, sınıf düzeyine ve cinsiyete göre farklılaşmasının incelenmesinde Mann-Whitney U ve Kruskal Wallis Testleri kullanılmasına karar verilmiştir.

Öğrencilerin problem çözmeye yönelik inancının okul türüne göre farklılaşmasının incelenmesinde kullanılan Kruskal Wallis Analiz sonuçları Tablo 3 de sunulmuş olup problem çözmeye yönelik inancın okul türüne göre farklılaşmakta olduğu bulgusuna ulaşılmıştır. Analiz sonuçlarına göre fen lisesi öğrencilerinin problem çözmeye yönelik inancın diğer lise türlerine göre daha olumlu olduğu sonucuna ulaşılmıştır. Anadolu lisesi öğrencilerininde meslek lisesi ve sosyal bilimler lisesi öğrencilerinden daha olumlu olduğu görülmüştür. Meslek lisesi ile sosyal bilimler lisesi öğrencilerinin ise problem çözmeye yönelik inançları arasında istatistiksel bakımdan kaydadeğer bir farklılık bulunmadığı sonucuna ulaşılmıştır.

Tablo 3. Öğrencilerin Problem Çözmeye Yönelik İnancının Okul Türüne Göre Farklılaşmasının Incelenmesi Kruskal Wallis Analiz Sonuçları

\begin{tabular}{|c|c|c|c|c|c|c|}
\hline & Okul Türü & $\mathrm{N}$ & S1ra ortalamas1 & Chi-kare & $\mathrm{Sd}$ & $\mathrm{p}$ \\
\hline \multirow{4}{*}{$\begin{array}{l}\text { Problem } \\
\text { Çözme }\end{array}$} & meslek lisesi & 144 & 181,75 & & & \\
\hline & fen lisesi & 44 & 259,69 & & & \\
\hline & anadolu lisesi & 138 & 237,37 & 25,710 & 3 &, 000 \\
\hline & sosyal bilimler lisesi & 92 & 187,13 & & & \\
\hline \multirow{4}{*}{$\begin{array}{c}\text { Matematiksel } \\
\text { Beceri }\end{array}$} & meslek lisesi & 144 & 188,00 & & & \\
\hline & fen lisesi & 44 & 242,81 & & & \\
\hline & anadolu lisesi & 138 & 232,51 & 14,830 & 3 & ,002 \\
\hline & sosyal bilimler lisesi & 92 & 192,71 & & & \\
\hline \multirow{4}{*}{$\begin{array}{l}\text { Matematiğin } \\
\text { Yeri }\end{array}$} & meslek lisesi & 144 & 198,17 & & & \\
\hline & fen lisesi & 44 & 215,83 & & & \\
\hline & anadolu lisesi & 138 & 225,63 & 4,435 & 3 & ,218 \\
\hline & sosyal bilimler lisesi & 92 & 200,01 & & & \\
\hline \multirow{5}{*}{$\begin{array}{l}\text { Problemi } \\
\text { Anlama }\end{array}$} & meslek lisesi & 144 & 177,13 & & & \\
\hline & fen lisesi & 44 & 285,76 & & & \\
\hline & anadolu lisesi & 138 & 230,46 & 34,074 & 3 & ,000 \\
\hline & sosyal bilimler lisesi & 92 & 192,27 & & & \\
\hline & meslek lisesi & 144 & 180,75 & & & \\
\hline
\end{tabular}


Ortaöğretim Öğrencilerinin Problem Çözmeye Yönelik İnançları ve Akademik Özyeterlilik Algılarının Çeşitli Değişkenlere Göre İncelenmesi

\begin{tabular}{|c|c|c|c|c|c|c|}
\hline \multirow{3}{*}{$\begin{array}{l}\text { Matematiğin } \\
\text { Önemi }\end{array}$} & fen lisesi & 44 & 230,18 & & & \\
\hline & anadolu lisesi & 138 & 245,22 & 23,925 & 3 & ,000 \\
\hline & sosyal bilimler lisesi & 92 & 191,03 & & & \\
\hline \multirow{5}{*}{$\begin{array}{l}\text { Problem çözme } \\
\text { becerisi }\end{array}$} & meslek lisesi & 144 & 210,83 & & & \\
\hline & fen lisesi & 44 & 246,99 & & & \\
\hline & anadolu lisesi & 138 & 202,37 & 5,368 & 3 & 147 \\
\hline & sosyal bilimler lisesi & 92 & 200,19 & & & \\
\hline & Toplam & 418 & & & & \\
\hline
\end{tabular}

Okul türüne göre problem çözmeye yönelik inancın altboyutlar, problem çözme, matematiksel beceri, matematiğin yeri, problemi anlama, matematiğin önemi ve problemçözme becerisi olarak bakıldığından fen lisesi öğrencileri ile diğer lise türleri öğrencilerinde arasında kaydadeğer bir farklılık olduğu görülmektedir. Problem çözme, matematiksel beceri ve matematiğin yeri faktörleri bakımından meslek lisesi ile sosyal bilimler lisesi arasında anlamlı bir farklılık gözükmemektedir. Problem çözme, matematiğin yeri, problemi anlama, matematiğin önemi ve problem çözme becerisi bakımından fen lisesi ve Anadolu lisesi öğrencileri arasında fen lisesi lehine kaydadeğer farklılık gözükmektedir. Problem çözme faktöründe anlamlı farklılık meslek lisesi lehinde iken diğer alt faktörlerde meslek lisesi alehine anlamlı bir farklılık görülmektedir.

Okul türleri göre ortalamalar arasında kaydadeğer bir fark olduğunu görebilmek için Mann Whitney U testi ile belirlenmiştir.

Tablo 4. Problem Çözmeye Yönelik İnancın Toplam Puanları Ve Alt Boyut Puanlarının Meslek Lisesi Ve Fen Lisesine Göre Karşılaştırılması Mann Whitney U Testi Sonuçları

\begin{tabular}{|c|c|c|c|c|c|c|}
\hline & Okul Türü & $\mathrm{N}$ & $\begin{array}{c}\text { Sira } \\
\text { ortalamas1 }\end{array}$ & $\begin{array}{l}\text { Sira } \\
\text { toplam1 }\end{array}$ & $\begin{array}{l}\text { Mann- } \\
\text { Whitney U }\end{array}$ & $\mathrm{p}$ \\
\hline \multirow{2}{*}{ Problem çözme } & meslek lisesi & 144 & 86,54 & 12462,00 & & \\
\hline & fen lisesi & 44 & 120,55 & 5304,00 & 2022,000 & ,000 \\
\hline \multirow{2}{*}{$\begin{array}{l}\text { Matematiksel } \\
\text { beceri }\end{array}$} & meslek lisesi & 144 & 88,80 & 12787,50 & 2347,500 & ,009 \\
\hline & fen lisesi & 44 & 113,15 & 4978,50 & & \\
\hline \multirow{2}{*}{$\begin{array}{l}\text { Matematiğin } \\
\text { yeri }\end{array}$} & meslek lisesi & 144 & 92,68 & 13346,50 & 2906,500 & ,407 \\
\hline & fen lisesi & 44 & 100,44 & 4419,50 & & \\
\hline \multirow{2}{*}{$\begin{array}{l}\text { Problemi } \\
\text { anlama }\end{array}$} & meslek lisesi & 144 & 83,26 & 11990,00 & 1550,000 & ,000 \\
\hline & fen lisesi & 44 & 131,27 & 5776,00 & & \\
\hline \multirow{2}{*}{$\begin{array}{l}\text { Matematiğin } \\
\text { önemi }\end{array}$} & meslek lisesi & 144 & 89,50 & 12887,50 & 2447,500 & ,022 \\
\hline & fen lisesi & 44 & 110,88 & 4878,50 & & \\
\hline \multirow{3}{*}{$\begin{array}{l}\text { Problem çözme } \\
\text { becerisi }\end{array}$} & meslek lisesi & 144 & 90,68 & 13058,00 & 2618,000 & ,079 \\
\hline & fen lisesi & 44 & 107,00 & 4708,00 & & \\
\hline & Toplam & 188 & & & & \\
\hline
\end{tabular}

Fen lisesi öğrencilerinin Problem Çözmeye Yönelik İnanç ölçeğindeki problem çözme, matematiksel beceri, matematiğin yeri, problem anlama, matematiğin önemi ve problem çözme beceri bakımından meslek lisesi öğrencileri arasında fen lisesi ögrencileri lehine çok büyük kaydadeğer bir farklılık görülmektedir.

Tablo 5. Problem Çözmeye Yönelik İnancın Toplam Puanları ve Alt Boyut Puanlarının meslek lisesi ve Anadolu Lisesine Göre Karşılaştırılması Mann Whitney U Testi Sonuçları

\begin{tabular}{|c|c|c|c|c|c|c|}
\hline & Okul Türü & $\mathrm{N}$ & $\begin{array}{l}\text { Sira } \\
\text { ortalamas1 }\end{array}$ & $\begin{array}{l}\text { Sira } \\
\text { toplamı }\end{array}$ & $\begin{array}{c}\text { Mann- } \\
\text { whitney U }\end{array}$ & $\mathrm{p}$ \\
\hline \multirow{2}{*}{ Problem çözme } & meslek lisesi & 144 & 123,02 & 17715,00 & & \\
\hline & anadolu lisesi & 138 & 160,78 & 22188,00 & 7275,000 & ,000 \\
\hline \multirow{2}{*}{$\begin{array}{l}\text { Matematiksel } \\
\text { beceri }\end{array}$} & meslek lisesi & 144 & 126,77 & 18255,00 & 7815,000 &, 002 \\
\hline & anadolu lisesi & 138 & 156,87 & 21648,00 & & \\
\hline Matematiğin yeri & meslek lisesi & 144 & 132,44 & 19071,50 & 8631,500 & ,056 \\
\hline
\end{tabular}


Ortaöğretim Öğrencilerinin Problem Çözmeye Yönelik İnançları ve Akademik Özyeterlilik Algılarının Çeşitli Değişkenlere Göre İncelenmesi

\begin{tabular}{|c|c|c|c|c|c|c|}
\hline & anadolu lisesi & 138 & 150,95 & 20831,50 & & \\
\hline \multirow{2}{*}{ Problemi anlama } & meslek lisesi & 144 & 123,60 & 17799,00 & 7359,000 & ,000 \\
\hline & anadolu lisesi & 138 & 160,17 & 22104,00 & & \\
\hline \multirow{2}{*}{ Matematiğin önemi } & meslek lisesi & 144 & 120,12 & 17297,00 & 6857,000 &, 000 \\
\hline & anadolu lisesi & 138 & 163,81 & 22606,00 & & \\
\hline \multirow{3}{*}{$\begin{array}{l}\text { Problem } \\
\text { becerisi }\end{array}$} & meslek lisesi & 144 & 144,23 & 20768,50 & 9543,500 & ,563 \\
\hline & anadolu lisesi & 138 & 138,66 & 19134,50 & & \\
\hline & Toplam & 282 & & & & \\
\hline
\end{tabular}

Anadolu lisesi öğrencilerinin Problem Çözmeye Yönelik İnanç ölçeğindeki problem çözme, matematiksel beceri, matematiğin yeri, problem anlama ve matematiğin önemi bakımından meslek lisesi öğrencileri arasında fen lisesi öğrencileri lehine çok büyük kaydadeğer bir farklılık görülmektedir. Fakat problem çözme beceri bakımından çok büyük bir fark görülmemektedir.

Tablo 6. Problem Çözmeye Yönelik Inancın Toplam Puanları ve Alt Boyut Puanlarının Meslek Lisesi ve Sosyal Bilimler Lisesine Göre Karşılaştırılması Mann Whitney U Testi Sonuçları

\begin{tabular}{|c|c|c|c|c|c|c|}
\hline & Okul Türü & $\mathrm{N}$ & amas1 & Sira toplamı & $\begin{array}{c}\text { Mann- } \\
\text { Whitney U }\end{array}$ & $\mathrm{P}$ \\
\hline \multirow[b]{2}{*}{ Problem çözme } & meslek lisesi & 144 & 117,18 & 16874,50 & 6434,500 & ,711 \\
\hline & $\begin{array}{l}\text { sosyal bilimler } \\
\text { lisesi }\end{array}$ & 92 & 120,56 & 11091,50 & & \\
\hline \multirow{2}{*}{$\begin{array}{l}\text { Matematiksel } \\
\text { beceri }\end{array}$} & meslek lisesi & 144 & 117,43 & 16909,50 & & \\
\hline & $\begin{array}{l}\text { sosyal bilimler } \\
\text { lisesi }\end{array}$ & 92 & 120,18 & 11056,50 & 6469,500 & ,762 \\
\hline \multirow[b]{2}{*}{$\begin{array}{l}\text { Matematiğin } \\
\text { yeri }\end{array}$} & meslek lisesi & 144 & 118,05 & 16998,50 & & \\
\hline & $\begin{array}{l}\text { sosyal bilimler } \\
\text { lisesi }\end{array}$ & 92 & 119,21 & 10967,50 & 6558,500 & ,898 \\
\hline \multirow[b]{2}{*}{$\begin{array}{l}\text { Problemi } \\
\text { anlama }\end{array}$} & meslek lisesi & 144 & 115,26 & 16597,00 & & \\
\hline & $\begin{array}{l}\text { sosyal bilimler } \\
\text { lisesi }\end{array}$ & 92 & 123,58 & 11369,00 & 6157,000 & ,360 \\
\hline \multirow{2}{*}{$\begin{array}{l}\text { Matematiğin } \\
\text { önemi }\end{array}$} & meslek lisesi & 144 & 116,13 & 16723,00 & & \\
\hline & $\begin{array}{l}\text { sosyal bilimler } \\
\text { lisesi }\end{array}$ & 92 & 122,21 & 11243,00 & 6283,000 & ,503 \\
\hline \multirow{3}{*}{$\begin{array}{l}\text { Problem çözme } \\
\text { becerisi }\end{array}$} & meslek lisesi & 144 & 120,92 & 17413,00 & & \multirow{3}{*}{,491 } \\
\hline & $\begin{array}{l}\text { sosyal bilimler } \\
\text { lisesi }\end{array}$ & 92 & 114,71 & 10553,00 & 6275,000 & \\
\hline & Toplam & 236 & & & & \\
\hline
\end{tabular}

Meslek lisesi ile sosyal bilimler lisesi öğrencilerinin problemi anlama ve matematiğin önemi bakımından sosyal bilimler lisesi öğrencileri lehinde anlamlı bir farklılık görülmekte iken problem çözme becerisinde meslek lisesi öğrencileri lehinde anlamlı bir farklılık görülmektedir. Problem çözme, matematiksel beceri ve matematiğin yeri bakımından her iki lise türü öğrencileri arasında kaydadeğer bir farklılık gözlenmemektedir.

Tablo 7. Problem Çözmeye Yönelik Inancın Toplam Puanları ve Alt Boyut Puanlarının Anadolu Lisesi ve Fen Lisesine Göre Karşılaştırılması Mann Whitney U Testi Sonuçları

\begin{tabular}{|c|c|c|c|c|c|c|}
\hline & Okul Türü & $\mathrm{N}$ & $\begin{array}{l}\text { Sira } \\
\text { ortalamas1 }\end{array}$ & Sira toplamı & $\begin{array}{c}\text { Mann- } \\
\text { Whitney U }\end{array}$ & $\mathrm{P}$ \\
\hline \multirow{2}{*}{ Problem çözme } & fen lisesi & 44 & 99,85 & 4393,50 & & \\
\hline & anadolu lisesi & 138 & 88,84 & 12259,50 & 2668,500 & 227 \\
\hline \multirow{2}{*}{$\begin{array}{l}\text { Matematiksel } \\
\text { beceri }\end{array}$} & fen lis & 44 & 94,93 & 4177,00 & & \\
\hline & anadolu lisesi & 138 & 90,41 & 12476,00 & 2885,000 & 617 \\
\hline
\end{tabular}


Ortaöğretim Öğrencilerinin Problem Çözmeye Yönelik İnançları ve Akademik Özyeterlilik Algılarının Çeşitli Değişkenlere Göre İncelenmesi

\begin{tabular}{llrrrrr}
\hline $\begin{array}{l}\text { Matematiğin } \\
\text { yeri }\end{array}$ & fen lisesi & 44 & 88,24 & 3882,50 & & \\
\cline { 2 - 7 } $\begin{array}{l}\text { Problemi } \\
\text { anlama }\end{array}$ & anadolu lisesi & 138 & 92,54 & 12770,50 & 2892,500 &, 636 \\
\cline { 2 - 7 } $\begin{array}{l}\text { Matematiğin } \\
\text { onnemi }\end{array}$ & anadolu lisesi & 44 & 110,83 & 4876,50 & & \\
\hline \multirow{2}{*}{$\begin{array}{l}\text { Problem } \\
\text { becerisi }\end{array}$} & çözme lisesi & 44 & 87,68 & 3858,00 & &, 005 \\
\cline { 2 - 7 } & anadolu lisesi & 138 & 92,72 & 12795,00 & 2868,000 &, 578 \\
\cline { 2 - 7 } & fen lisesi & 44 & 106,56 & 4688,50 & & \\
\cline { 2 - 4 } & 138 & 86,70 & 11964,50 & 2373,500 &, 028 \\
\hline
\end{tabular}

Anadolu lisesive fen lisesi öğrencilerinin problem çözme, matematiksel beceri, matematiğin yeri ve matematiğin önemi bakımından aralarında kaydadeğer bir farklılık görülmemektedir. Problemi anlama ve problem çözme beceri bakımından fen lisesi öğrencileri lehine kaydadeğer bir farklılık görülmektedir.

Tablo 8. Problem Çözmeye Yönelik Inancın Toplam Puanlarl ve Alt Boyut Puanlarının Fen Lisesi ve Sosyal Bilimler Lisesine Göre Karşılaş̧tırılması Mann Whitney U Testi Sonuçları

\begin{tabular}{|c|c|c|c|c|c|c|}
\hline & Okul Türü & $\mathrm{N}$ & $\begin{array}{l}\text { Sira } \\
\text { ortalamas1 }\end{array}$ & $\begin{array}{l}\text { Sira } \\
\text { toplamı }\end{array}$ & $\begin{array}{l}\text { Mann- } \\
\text { Whitney U }\end{array}$ & $\mathrm{P}$ \\
\hline \multirow[b]{2}{*}{ Problem çözme } & fen lisesi & 44 & 84,30 & 3709,00 & & \\
\hline & $\begin{array}{ll}\text { sosyal bilimler } \\
\text { lisesi }\end{array}$ & 92 & 60,95 & 5607,00 & 1329,000 & ,001 \\
\hline \multirow{2}{*}{$\begin{array}{l}\text { Matematiksel } \\
\text { beceri }\end{array}$} & fen lisesi & 44 & 79,73 & 3508,00 & 1530,000 & ,021 \\
\hline & $\begin{array}{l}\text { sosyal bilimler } \\
\text { lisesi }\end{array}$ & 92 & 63,13 & 5808,00 & & \\
\hline \multirow[b]{2}{*}{ Matematiğin yeri } & fen lisesi & 44 & 72,15 & 3174,50 & 1863,500 & ,454 \\
\hline & $\begin{array}{ll}\text { sosyal bilimler } \\
\text { lisesi }\end{array}$ & 92 & 66,76 & 6141,50 & & \\
\hline \multirow[b]{2}{*}{ Problemi anlama } & fen lisesi & 44 & 88,66 & 3901,00 & & \\
\hline & $\begin{array}{l}\text { sosyal bilimler } \\
\text { lisesi }\end{array}$ & 92 & 58,86 & 5415,00 & 1137,000 & ,000 \\
\hline \multirow[b]{2}{*}{$\begin{array}{l}\text { Matematiğin } \\
\text { önemi }\end{array}$} & fen lisesi & 44 & 76,63 & 3371,50 & & \\
\hline & $\begin{array}{l}\text { sosyal bilimler } \\
\text { lisesi }\end{array}$ & 92 & 64,61 & 5944,50 & 1666,500 & ,095 \\
\hline \multirow{3}{*}{$\begin{array}{l}\text { Problem } \\
\text { becerisi }\end{array}$} & fen lisesi & 44 & 78,43 & 3451,00 & & \\
\hline & $\begin{array}{l}\text { sosyal bilimler } \\
\text { lisesi }\end{array}$ & 92 & 63,75 & 5865,00 & 1587,000 & (041 \\
\hline & Toplam & 136 & & & & \\
\hline
\end{tabular}

Problem Çözmeye Yönelik İnanç ölçeğinin problem çözme, matematiksel beceri, matematiğin yeri, problem anlama, matematiğin önemi ve problem çözme becerisi bakımından fen lisesi ve sosyal bilimler lisesi öğrencileri arasında fen lisesi öğrencileri lehine çok büyük kaydadeğer bir farklılık görülmektedir.

Tablo 9. Problem Çözmeye Yönelik İnancın Toplam Puanları ve Alt Boyut Puanlarının Anadolu Lisesive Sosyal Bilimler Lisesine Göre Karşılaştırılması Mann Whitney U Testi Sonuçları

\begin{tabular}{llrrrrr}
\hline & Okul Türü & N & $\begin{array}{l}\text { Sira } \\
\text { ortalaması }\end{array}$ & Sira toplamı & $\begin{array}{c}\text { Mann- } \\
\text { Whitney U }\end{array}$ & p \\
\hline Problem & anadolu lisesi & 138 & 126,75 & 17492,00 & & \\
\cline { 2 - 7 } çözme & sosyal bilimler lisesi & 92 & 98,62 & 9073,00 & 4795,000 &, 002 \\
\hline $\begin{array}{l}\text { Matematiksel } \\
\text { beceri }\end{array}$ & anadolu lisesi & 138 & 124,23 & 17144,00 & & \\
\cline { 2 - 8 } $\begin{array}{l}\text { Matematiğin } \\
\text { yeri }\end{array}$ & sosyal bilimler lisesi & 92 & 102,40 & 9421,00 & 5143,000 &, 014 \\
\cline { 2 - 8 } & anadolu lisesi & 138 & 121,14 & 16717,50 & & \\
\hline
\end{tabular}


Ortaöğretim Öğrencilerinin Problem Çözmeye Yönelik İnançları ve Akademik Özyeterlilik Algılarının Çeşitli Değişkenlere Göre İncelenmesi

\begin{tabular}{llrrrrr}
\hline $\begin{array}{l}\text { Problemi } \\
\text { anlama }\end{array}$ & anadolu lisesi & 138 & 123,95 & 17104,50 & & \\
\cline { 2 - 7 } $\begin{array}{l}\text { Matematiğin } \\
\text { önemi }\end{array}$ & sosyal bilimler lisesi & 92 & 102,83 & 9460,50 & 5182,500 &, 018 \\
\cline { 2 - 7 } & anadolu lisesi & 138 & 127,69 & 17621,50 & & \\
\hline \multirow{2}{*}{$\begin{array}{l}\text { Problem } \\
\text { çözme becerisi }\end{array}$} & sosyal bilimler lisesi & 92 & 97,21 & 8943,50 & 4665,500 &, 001 \\
\cline { 2 - 7 } & anadolu lisesi & 138 & 116,01 & 16009,50 & & \\
\cline { 2 - 7 } & Sosyal bilimler lisesi & 92 & 114,73 & 10555,50 & 6277,500 &, 886 \\
\hline
\end{tabular}

Anadolu lisesi öğrencilerinin problem çözme becerisi bakımından sosyal bilimler lisesi öğrencileri arasında anadolu lisesi öğrencileri lehine anlamlı bir farklılık gezlenmez iken diğer alt faktörlerde anadolu lisesi öğrencileri lehine anlamlı bir farklılık gözlenmektedir.

Sonuç olarak, Problem Çözmeye Yönelik İnanç okul türüne göre farklılaştığı görülmektedir. Fen lisesi ögrencilerinin Problem Çözmeye Yönelik İnancın toplam ve alt boyut puanları bakımından diğer lise türleri arasında anlamlı bir farklık olduğu görülmektedir. Fen lisesi öğrencilerinin problemi anlama ve problem çözme becerisi alt boyutu puanları anadolu lisesi öğrencilerinden daha yüksek olduğu görülmektedir. Fen lisesi öğrencilerinin Problem Çözmeye Yönelik İnancın toplam ve matematiksel beceri, matematiğin önemi, problemi anlama alt boyut puanları meslek lisesi öğrencilerinden daha yüksek olduğu görülmektedir. Anadolu lisesi öğrencilerinin Problem Çözmeye Yönelik İnancın toplam ve matematiksel beceri, problemi anlama ve matematiğin önemi alt boyutu puanlarının meslek lisesi öğrencilerinden daha yüksek olduğu görülmektedir. Anadolu lisesi öğrencilerinin Problem Çözmeye Yönelik İnancın toplam ve matematiksel beceri, matematiğin önemi ve problemi anlama alt boyut puanlarının sosyal bilimler lisesi öğrencilerinden daha yüksek olduğu bulunmuştur. Sosyal bilimler lisesi ve meslek lisesi öğrencilerinin ise Problem Çözmeye Yönelik İnancın hem toplam puan hem de alt boyut puanları arasında istatistiksel olarak anlamlı bir farklı1ık olmadığı görülmüştür.

Tablo 10. Öğrencilerin matematiksel problem çözmeye yönelik inançları sinıf düzeyine göre incelenmesi Mann Whitney testi

\begin{tabular}{|c|c|c|c|c|c|c|}
\hline & Okul Türü & $\mathrm{N}$ & $\begin{array}{c}\text { Sira } \\
\text { ortalamas1 } \\
\end{array}$ & Sira toplamı & $\begin{array}{c}\text { Mann- } \\
\text { Whitney U }\end{array}$ & $\mathrm{p}$ \\
\hline \multirow{2}{*}{ Problem çözme } & 9. sinif & 217 & 214,25 & 46491,50 & & \\
\hline & 12. sinif & 201 & 204,38 & 41079,50 & 20778,500 & ,404 \\
\hline \multirow{2}{*}{$\begin{array}{l}\text { Matematiksel } \\
\text { beceri }\end{array}$} & 9. sinif & 217 & 211,09 & 45807,00 & & \\
\hline & 12. sinif & 201 & 207,78 & 41764,00 & 21463,000 & ,778 \\
\hline \multirow{2}{*}{$\begin{array}{l}\text { Matematiğin } \\
\text { yeri }\end{array}$} & 9. sinif & 217 & 210,22 & 45617,50 & & \\
\hline & 12. $\sin 1 f$ & 201 & 208,72 & 41953,50 & 21652,500 & 899 \\
\hline \multirow{2}{*}{$\begin{array}{l}\text { Problemi } \\
\text { anlama }\end{array}$} & 9. sinif & 217 & 212,11 & 46027,00 & & \\
\hline & 12. sinif & 201 & 206,69 & 41544,00 & 21243,000 & ,646 \\
\hline \multirow{2}{*}{$\begin{array}{l}\text { Matematiğin } \\
\text { önemi }\end{array}$} & 9. sinif & 217 & 217,47 & 47191,50 & & \\
\hline & 12. $\sin 1 f$ & 201 & 200,89 & 40379,50 & 20078,500 & ,159 \\
\hline \multirow{3}{*}{$\begin{array}{l}\text { Problem çözme } \\
\text { becerisi }\end{array}$} & 9. sinıf & 217 & 214,58 & 46563,00 & & \\
\hline & 12. sinif & 201 & 204,02 & 41008,00 & 20707,000 & ,368 \\
\hline & Toplam & 418 & & & & \\
\hline
\end{tabular}

Yukarıdaki tablo incelendiğinde Mann Whitney Analiz sonuçlarına göre 9. sınıf öğrencileri ile 12. sınıf öğrencileri arasında problem çözme, problem çözme becerisi, matematiğin önemi ve problemi anlama bakımından lise son sınıf öğrenleri lehine kaydadeğer bir farklılık gözlenmektedir. Matematiksel beceri ve matematiğin yeri bakımından sınıf seviyeleri arasında kaydadeğer bir farklılık gözlenmemektedir. 
Tablo 11. Öğrencilerin problem çözmeye yönelik inançlarının cinsiyete göre incelenmesi Mann Whitney U testi

\begin{tabular}{|c|c|c|c|c|c|c|}
\hline & Cinsiyet & $\mathrm{N}$ & $\begin{array}{c}\text { Sira } \\
\text { ortalamas1 }\end{array}$ & $\begin{array}{c}\text { Sira } \\
\text { toplamı }\end{array}$ & $\begin{array}{c}\text { Mann- } \\
\text { Whitney U }\end{array}$ & $\mathrm{p}$ \\
\hline \multirow[t]{2}{*}{ Problem Çözme } & $\mathrm{K} 1 \mathrm{Z}$ & 242 & 224,08 & 54227,50 & & \\
\hline & Erkek & 176 & 189,45 & 33343,50 & 17767,500 & ,004 \\
\hline \multirow{2}{*}{$\begin{array}{l}\text { Matematiksel } \\
\text { beceri }\end{array}$} & Kiz & 242 & 223,11 & 53993,00 & & \\
\hline & Erkek & 176 & 190,78 & 33578,00 & 18002,000 & ,007 \\
\hline \multirow{2}{*}{$\begin{array}{l}\text { Matematiğin } \\
\text { yeri }\end{array}$} & $\mathrm{K} 1 \mathrm{z}$ & 242 & 216,90 & 52489,00 & & \\
\hline & Erkek & 176 & 199,33 & 35082,00 & 19506,000 & ,141 \\
\hline \multirow{2}{*}{$\begin{array}{l}\text { Problemi } \\
\text { anlama }\end{array}$} & $\mathrm{K} 1 \mathrm{z}$ & 242 & 218,67 & 52917,50 & & \\
\hline & Erkek & 176 & 196,89 & 34653,50 & 19077,500 & ,068 \\
\hline \multirow{2}{*}{$\begin{array}{l}\text { Matematiğin } \\
\text { önemi }\end{array}$} & Kiz & 242 & 218,08 & 52774,50 & & \\
\hline & Erkek & 176 & 197,71 & 34796,50 & 19220,500 & 087 \\
\hline \multirow{3}{*}{$\begin{array}{l}\text { Problem çözme } \\
\text { becerisi }\end{array}$} & $\mathrm{K}_{1 \mathrm{Z}}$ & 242 & 215,99 & 52270,00 & & \\
\hline & Erkek & 176 & 200,57 & 35301,00 & 19725,000 & ,194 \\
\hline & Toplam & 418 & & & & \\
\hline
\end{tabular}

Cinsiyete göre problem çözmeye yönelik inançları incelendiğinde, öğrencilerin problem çözmeye yönelik inançları toplam puanları ile sadece matematiksel beceri boyutu puanları arasında kızlar lehine istatistiksel olarak anlamlı bir fark tespit edilmiștir. Cinsiyete göre problem çözmeye yönelik inancın toplam puanları ile matematiksel beceri boyutu puanları açısından kız öğrenciler lehine istatistiksel olarak anlamlı düzeyde bir farklılık bulunurken, matematiğin yeri boyutu, problemi anlama boyutu, matematiğin önemi boyutu ve problem çözme becerisi boyutu puanları açısından anlamlı bir fark yoktur. Bir başka deyişle, kız öğrencilerin problem çözmeye yönelik inancın toplam puanları ile matematiksel beceri boyutu puanları açısından erkek öğrencilere kıyasla daha olumludur.

\section{Öğrencilerin akademik özyeterlilik algıları okul türüne göre istatistiksel olarak anlamlı bir farklılık oluşturmakta mıdır?}

Tablo 12. Öğrencilerin Problem Çözmeye Yönelik Inancının Okul Türüne Göre Farklılaşmasının Incelenmesi Kruskal Wallis Analiz Sonuçları

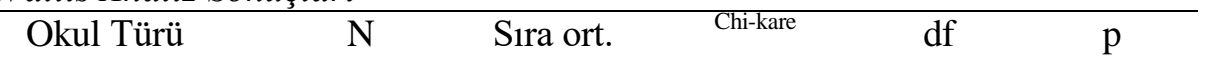

\begin{tabular}{|c|c|c|c|c|c|c|}
\hline \multirow{5}{*}{$\begin{array}{l}\text { Akademik } \\
\text { özyeterlilik } \\
\text { algıları }\end{array}$} & meslek lisesi & 144 & 175,38 & & & \\
\hline & fen lisesi & 44 & 232,94 & & & \\
\hline & anadolu lisesi & 138 & 228,53 & 17,749 & 3 & ,000 \\
\hline & $\begin{array}{l}\text { sosyal bilimler } \\
\text { lisesi lisesi }\end{array}$ & 92 & 223,15 & & & \\
\hline & Toplam & 418 & & & & \\
\hline
\end{tabular}

Öğrencilerin akademik özyeterlilik algılarının okul türüne göre farklılaşmasının incelenmesinde akademik özyeterlilik algılarının okul türüne göre farklılaşmakta olduğu bulgusuna ulaşılmaktadır. Analiz sonuçları değerlendirildiğinde sıra ortalamalarına göre fen lisesi öğrencilerinin akademik özyeterlilik algılarının diğer lise öğrencilerinden daha olumlu olduğu görülmektedir. Anadolu lisesi öğrencilerinin akademik özyeterlilik algılarının meslek lisesi ve sosyal bilimler lisesi öğrencilerinden 
daha olumlu olduğu gözlenmektedir. Sosyal bilimler lisesi öğrencilerinin akademik özyeterlilik algıları meslek lisesi öğrencilerinden daha olumlu olduğu sonucuna varılabilir. Akademik özyeterlilik algıları bakımından sıralandığında fen lisesi, anadolu lisesi, sosyal bilimler lisesi ve meslek lisesi şeklinde bir sıralama yapılabilir.

Öğrencilerin Akademik Özyeterlilik Algılarının lise türlerinin bir birleri ile karşılaştırması Mann Whitney U Testi ile arasında istatistiksel olarak sonuçları aşağıdaki tabloda ifade edilmiştir.

Tablo 13. Akademik Özyeterlilik Algıları Puanlarının Lise Dğişkenlerine Göre Karşılaştırılması Mann Whitney U Testi Sonuçları

\begin{tabular}{|c|c|c|c|c|c|c|}
\hline & Okul Türü & $\mathrm{N}$ & $\begin{array}{l}\text { Sira } \\
\text { ortalamas1 }\end{array}$ & Sira toplamı & $\begin{array}{l}\text { Mann- } \\
\text { Whitney U }\end{array}$ & $\mathrm{p}$ \\
\hline \multirow{3}{*}{$\begin{array}{l}\text { Akademik } \\
\text { özyeterlilik } \\
\text { algıları }\end{array}$} & meslek lisesi & 144 & 88,48 & 12740,50 & & \\
\hline & fen lisesi & 44 & 114,22 & 5025,50 & 2300,5 & ,006 \\
\hline & Toplam & 188 & & & & \\
\hline \multirow{3}{*}{$\begin{array}{l}\text { Akademik } \\
\text { özyeterlilik } \\
\text { algıları }\end{array}$} & meslek lisesi & 144 & 123,50 & 17783,50 & & \\
\hline & anadolu lisesi & 138 & 160,29 & 22119,50 & 7343,500 &, 000 \\
\hline & Toplam & 282 & & & & \\
\hline \multirow{3}{*}{$\begin{array}{l}\text { Akademik } \\
\text { özyeterlilik } \\
\text { algıları }\end{array}$} & meslek lisesi & 144 & 108,41 & 15610,50 & 5170,500 &, 004 \\
\hline & $\begin{array}{l}\text { sosyal bilimler } \\
\text { lisesi }\end{array}$ & 92 & 134,30 & 12355,50 & & \\
\hline & Toplam & 236 & & & & \\
\hline \multirow{3}{*}{$\begin{array}{l}\text { Akademik } \\
\text { özyeterlilik } \\
\text { algiları }\end{array}$} & fen lisesi & 44 & 93,66 & 4121,00 & & \\
\hline & anadolu lisesi & 138 & 90,81 & 12532,00 & 2941,000 & ,755 \\
\hline & Toplam & 182 & & & & \\
\hline \multirow{3}{*}{$\begin{array}{l}\text { Akademik } \\
\text { özyeterlilik } \\
\text { algiları }\end{array}$} & fen lisesi & 44 & 70,07 & 3083,00 & & \\
\hline & $\begin{array}{l}\text { sosyal bilimler } \\
\text { lisesi }\end{array}$ & 92 & 67,75 & 6233,00 & 1955,000 & ,748 \\
\hline & Toplam & 136 & & & & \\
\hline \multirow{3}{*}{$\begin{array}{l}\text { Akademik } \\
\text { özyeterlilik } \\
\text { algıları }\end{array}$} & anadolu lisesi & 138 & 116,43 & 16068,00 & & \\
\hline & $\begin{array}{ll}\text { sosyal bilimler } \\
\text { lisesi }\end{array}$ & 92 & 114,10 & 10497,00 & 6219,000 & ,794 \\
\hline & Toplam & 230 & & & & \\
\hline
\end{tabular}

Fen lisesive meslek lisesi öğrencilerinin akademik özyeterlilik algıları karşılaştırıldığında fen lisesi öğrencileri lehine kaydadeğer bir fark gözlenmektedir. Fen lisesi öğrencilerinin akademik özyeterlilik algıları puanları $\left(\bar{X}_{\text {srra }}=114,22\right)$, meslek lisesi öğrencilerinin akademik özyeterlilik algıları toplam puanlarından $\left(\bar{X}_{\text {srra }}=88,48\right)$ kaydadeğer seviyeden daha yüksek olduğu görülmektedir. $[\mathrm{U}=2300,5, \mathrm{p}=$ .000]. Anadolu lisesi ve meslek lisesi öğrencilerinin akademik özyeterlilik algıları karşılaştırıldığında akademik özyeterlilik algıları puanları arasında anadolu lisesi öğrencileri lehine kaydadeğer bir fark gözlenmektedir. Anadolu lisesi öğrencilerinin akademik özyeterlilik algıları puanları $\left(\bar{X}_{\text {sra }}=160.29\right)$, meslek lisesi öğrencilerinin akademik özyeterlilik algıları puanlarından $\left(\bar{X}_{\text {srra }}=123.50\right)$ istatistiksel olarak anlamlı düzeyden daha yüksek olduğu gözlenmektedir. [ $\mathrm{U}=7343,500, \mathrm{p}=.000]$. Meslek lisesi ve sosyal bilimler lisesi öğrencilerinin akademik özyeterlilik algıları karşılaştırıldığında akademik özyeterlilik algıları puanları arasında sosyal bilimler lisesi öğrencileri lehine kaydadeğer bir fark bulunmuştur. Öyle ki, sosyal bilimler lisesi öğrencilerinin akademik özyeterlilik algıları puanları $\left(\bar{X}_{\text {sra }}=134,30\right)$, meslek lisesi öğrencilerinin akademik özyeterlilik algıları puanlarından $\left(\bar{X}_{\text {srra }}=108,41\right)$ istatistiksel olarak kaydadeğer düzeyde daha yüksek görülmektedir. [U $=5170,500, p=.004]$. Meslek lisesi ve sosyal bilimler lisesi öğrencilerinin akademik özyeterlilik algıları karşılaştırıldığında akademik özyeterlilik algıları puanları arasında kaydadeğer bir fark görülmemektedir. $[\mathrm{U}=2941,000, \mathrm{p}=$. 755]. Fen lisesive sosyal bilimler lisesi öğrencilerinin akademik özyeterlilik algıları karşılaştııldı̆̆ında akademik 
özyeterlilik algıları puanları arasında kaydadeğer bir fark gözlenmektedir. [U =1955,000, p= . 748]. Anadolu lisesive sosyal bilimler lisesi öğrencilerinin akademik özyeterlilik algıları karşılaştırıldığında akademik özyeterlilik algıları puanları arasında kaydadeğer bir fark bulunmamıştır. $[\mathrm{U}=6219,000, \mathrm{p}=$. 794]. Sonuç olarak, akademik özyeterlilik algıları okul türüne göre farklılaşmaktadır. Ancak bu farklılık sadece meslek lisesinin diğer lise türleriyle kıyaslanmasında diğer liseler lehine kaydadeğer bir farklılık oluşturmaktadır. Fen Lisesi-anadolu lisesi, fen lisesi-sosyal bilimler lisesi ve anadolu lisesi-Sosyal bilimler lisesi akademik özyeterlilik algıları puanları arasında istatistiksel olarak kaydadeğer bir farklılık gözlenmemektedir.

Tablo 14. Öğrencilerin Akademik Özyeterlilik Algllarının Sinıf Düzeyine Göre İncelenmesi Mann Whitney U-testi

\begin{tabular}{ccccccc}
\hline & Sinıf Seviyesi & N & $\begin{array}{c}\text { Sira } \\
\text { ortalamas }\end{array}$ & Sira toplamı & $\begin{array}{c}\text { Mann- } \\
\text { Whitney U }\end{array}$ & p \\
\hline $\begin{array}{c}\text { Akademik } \\
\text { özyeterlilik } \\
\text { algiları }\end{array}$ & 9. sınıf & 217 & 201,45 & 43714,50 & & \\
\cline { 2 - 7 } & 12. sinıf & 201 & 218,19 & 43856,50 & 20061,500 &, 157 \\
\cline { 2 - 7 } & Toplam & 418 & & & & \\
\hline
\end{tabular}

Öğrencilerin akademik özyeterlilik algıları sınıf seviyesine göre istatistiksel yönden kaydadeğer bir farklılık olmadığı neticesine ulaşılmıştır [U=20061,500 p=,157].

Tablo 15. Öğrencilerin Akademik Özyeterlilik Algılarının Cinsiyete Göre İncelenmesi Mann Whitney U testi

\begin{tabular}{ccccccc}
\hline & cinsiyet & $\mathrm{N}$ & $\begin{array}{c}\text { Sira } \\
\text { ortalamas1 }\end{array}$ & $\begin{array}{c}\text { Sira } \\
\text { toplamı }\end{array}$ & $\begin{array}{c}\text { Mann- } \\
\text { whitney U }\end{array}$ & $\mathrm{p}$ \\
\hline $\begin{array}{c}\text { Akademik } \\
\text { özyeterlilik } \\
\text { algiları }\end{array}$ & K1z & 242 & 216,98 & 52510,00 & & \\
\cline { 2 - 7 } & Erkek & 176 & 199,21 & 35061,00 & 19485,00 &, 137 \\
\cline { 2 - 7 } & Toplam & 418 & & & & \\
\hline
\end{tabular}

Öğrencilerin akademik özyeterlilik algıları cinsiyete göre farklılaşmasını incelendiğginde aralarında kaydadeğer bir farklık olmadığı görülmüştür.

Tablo 16. İnanç Ölçeği Faktörleri ile Akademik Yeterlilik Spearman Korelasyon Testi

\begin{tabular}{|c|c|c|c|c|c|c|c|}
\hline \multirow{4}{*}{ 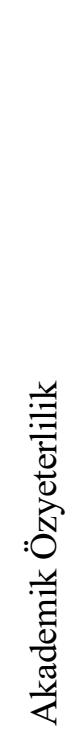 } & & 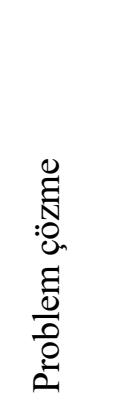 & 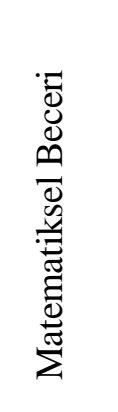 & 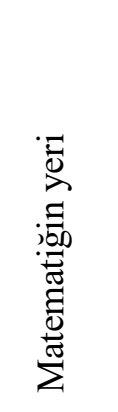 & 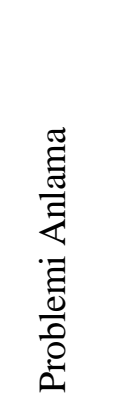 & 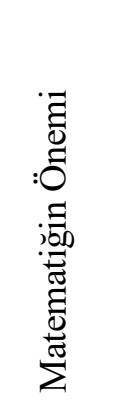 & 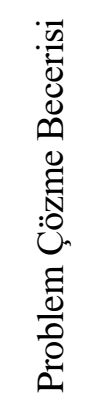 \\
\hline & $\mathrm{R}$ &, $365^{* *}$ &, $297^{* *}$ &, $238^{* *}$ &, $303^{* *}$ &, $344^{* *}$ &, $028^{* * *}$ \\
\hline & $\mathrm{P}$ & ,000 & ,000 & ,000 & ,000 & ,000 & ,000 \\
\hline & $\mathrm{N}$ & 418 & 418 & 418 & 418 & 418 & 418 \\
\hline
\end{tabular}

Matematiksel problem çözmeye yönelik inanç ölçeğinin matematiğin yeri faktörü ile öğrencilerin akademik özyeterlilik algısı arasında pozitif yönde düşük düzeyde istatistiksel bakımdan kaydadeğer bir ilişki vardır $(\mathrm{r}=.238, \mathrm{p}=.000)$. Buna göre akademik özyeterlilik algıları matematiğin yerinin \% 6 sını 
açıklamaktadır $\left(R^{2} \cong 0,06\right)$. Matematiksel problem çözmeye yönelik inanç ölçeğinin problemi anlama faktörü ile öğrencilerin akademik özyeterlilik algısı arasında pozitif yönde orta düzeyde istatistiksel bakımdan kaydadeğer bir ilişki vardır $(\mathrm{r}=.303, \mathrm{p}=.000)$. Buna göre akademik özyeterlilik algıları problem çözmeye yönelik inançların \%13 ünü açılamaktadır $\left(R^{2} \cong 0,13\right)$. Matematiksel problem çözmeye yönelik inanç ölçeğinin matematiğin önemi faktörü ile öğrencilerin akademik özyeterlilik algısı arasında pozitif yönde orta düzeyde istatistiksel bakımdan kaydadeğer bir ilişki vardır $(\mathrm{r}=.344, \mathrm{p}=.000)$. Buna göre akademik özyeterlilik algıları matematiğin öneminin $\% 12$ sini açıklamaktadır $\left(R^{2} \cong 0,12\right)$. Matematiksel problem çözmeye yönelik inanç ölçeğinin problem çözme becerisi faktörü ile öğrencilerin akademik özyeterlilik algısı arasında istatistiksel bakımdan kaydadeğer bir ilişki bulunmamaktadır ( $\mathrm{r}=.028, \mathrm{p}=.570$ ). Matematiksel problem çözmeye yönelik inanç ölçeğinin matematiksel beceri faktörü ile öğrencilerin akademik özyeterlilik algısı arasında pozitif yönde düşük düzeyde istatistiksel bakımdan kaydadeğer bir ilişki vardır ( $\mathrm{r}=.297, \mathrm{p}=.000$ ). Buna göre akademik özyeterlilik algıları matematiksel becerinin \% 9 unu açıklamaktadır $\left(R^{2} \cong 0,09\right)$. Öğrencilerin problem çözmeye yönelik inançları ile öğrencilerin akademik özyeterlilik algıları arasında istatistiksel olarak pozitif yönde orta düzeyde kaydadeğer bir ilişki vardır $(\mathrm{r}=.365, \mathrm{p}=.000)$. Buna göre akademik özyeterlilik algıları problem çözmeye yönelik inançların \%13 ünü açıklamaktadır $\left(R^{2} \cong 0,13\right)$.

\section{SONUÇ}

Öğrencilerin problem çözmeye yönelik inançlarının okul türüne göre farklılaşmakta olduğu bulgusuna ulaşı1mıştır. Okul türüne göre fen lisesi öğrencilerinin problem çözmeye, matematiksel beceri, yönelik inançlarının hem toplam hem de alt boyutlar açısından diğer lise öğrencilerinin problem çözmeye yönelik inançlarından daha olumlu olduğu bulunmuştur. Fen lisesinde öğrenim gören öğrencilerin problem çözmeye yönelik inançlarının diğer lise türlerinde okuyan öğrencilerinden daha olumlu olduğu görülmüsstür. Anadolu lisesinde öğrenim gören öğrencilerinin problem çözmeye yönelik inançlarının meslek lisesi ve sosyal bilimler lisesi öğrencilerinden daha olumlu olduğu görülmüştür. Diğer liselerde öğrenim gören öğrencilerinin ise problem çözmeye yönelik inançları arasında istatistiksel bakımdan kaydadeğer bir farklılık olmadığı sonucuna ulaşılmıştır. Benzer sonuç (Korkut, 2002) problem çözme becerisi üzerinde okul türü parametresi bakımında istatistiksel bakımdan kaydadeğer bir farklılık elde etmiştir. Fakat diğer bir çalışma, okul türü değişkeninin problem çözme becerisi üzerinde istatistiksel bakımdan kaydadeğer bir farklılık oluşturmadığı sonucuna ulaşmıştır (Erdem, 2006). Matematik alanında başarılı olan ve liselere giriş sınavı puanı ile öğrenci alan fen lisesi, sosyal bilimler lisesi veya anadolu lisesini kazanan öğrencilerin problem çözmeye yönelik olumlu inanca sahip olabilecekleri ve matematiksel problem çözmede başarılı olamadıkları için daha düşük puanlar ile meslek liselerine giden öğrencilerin matematiksel problem çözmeye yönelik olumsuz inanç sahip olabilecekleri gibi bir genelleme yapılacak olursa; bu durum okul türü açısından meslek lisesine giden öğrencilerin matematiksel problem çözmeye yönelik inançlarının diğer okul türlerinden daha düşük olmasının bir açıklaması olabilir.

Problem çözmeye yönelik inancın toplam puanları ile matematiksel beceri boyutu puanları açısından kız öğrenciler lehine istatistiksel bakımdan kaydadeğer düzeyde bir farklılık bulunurken, matematiğin yeri boyutu, problemi anlama boyutu, matematiğin önemi boyutu ve problem çözme becerisi boyutu puanları açısından kaydadeğer bir fark yoktur. Bir başka deyişle, kız öğrencilerin problem çözmeye yönelik inancın toplam puanları ile matematiksel beceri boyutu puanları açısından erkek ögrencilere kıyasla daha olumludur. Bu durum Develioğlu (2006) ve Açık (2013) çalışmalarında ise problem çözme becerilerinin cinsiyet değişkeni bakımından kızlar lehine istatistiksel olarak anlamlı bir farklılık olduğunu belirtmektedirler. Bilgin (2010), Behjoo (2013) çalışmalarında problem çözme becerilerinin cinsiyet parametresi bakımından istatistiksel olarak kaydadeğer bir farklılık olmadığını belirtmektedirler. Kız öğrenciler bilişsel gelişimlerindeki farklılıklar nedeniyle matematiğin meslekleri için gerekli ve önemli olduğunu erkek öğrencilere kıyasla daha erken analiz etmeye başliyor olabilirler.

Akademik özyeterlilik algıları okul türüne göre farklılaşmaktadır. Ancak bu farklılık sadece meslek lisesinin diğer lise türleriyle kıyaslanmasında diğer liseler lehine kaydadeğer bir farkl111k 
oluşturmaktadır. Fen lisesi-anadolu lisesi, fen lisesi-sosyal bilimler lisesi ve anadolu lisesi-sosyal bilimler lisesi akademik özyeterlilik algıları puanları arasında istatistiksel bakımdan kaydadeğer bir farklılık bulunmamıştır. Kurbanoğlu ve Takunyacı'ya (2012) göre öğrenim gördükleri okul türlerine göre lise öğrencilerinin matematik dersine yönelik öz-yeterlik inançları arasında anlamlı bir farklılık gösterdiğini ifade etmektedirler. 9. Sınıf öğrencilerin problem çözmeye; akademik özyeterlilik algıları ile 12. Sınıf öğrencilerin akademik özyeterlilik algıları arasında istatistiksel bakımdan kaydadeğer bir farklılık olmadığı bulgusuna ulaşılmıştır. Çeşitli yeterlik alanları üzerine dikkat çeken 2013 yılı Öğretim programının ilk mezun öğrencileri olan 12. Sınıf öğrencileri ile 2013 yılı Öğretim programının yeni ögrencileri olan 9. Sınıfları arasında akademik özyeterlilik bakımından istatistiksel olarak bir farklılık bulunmamıştır. Öğrencilerin akademik özyeterlilik algıları cinsiyete göre farklılaşmasının incelenmesinde akademik özyeterlilik algıları arasında istatistiksel bakımdan kaydadeğer bir farklılık olmadığı bulgusuna ulaşılmıştır. $\mathrm{Bu}$ sonuca benzer olarak, öğrencilerin ilk sekiz yıllık eğitimleri sürecinde cinsiyet ile matematikteki başarımları arasında anlamlı bir farklılığın olmadığı gözlenirken, daha sonraki eğitim sürecinde öğrencilerin cinsiyet ile matematikteki başarımları arasında anlamlı farklı1ık olduğunu gözlemektedir (Özlü, 2001). Bu araştırmada öğrencilerin problem çözmeye yönelik inançları ile akademik özyeterlilikleri arasında pozitif yönde orta seviyede istatistiksel olarak anlamlı bir ilişki bulunmuştur. Problem çözmeye yönelik inanç ölçeğinin alt faktörlerinden matematiksel beceri, matematiğin yeri, problemi anlama ve matematiğin önemi ile akademik özyeterlilik algısı arasında pozitif yönde anlamlı bir ilişki bulunurken problem çözmeye yönelik inanç ölçeğinin problem çözme becerisi alt faktörü ile akademik özyeterlilik algısı arasında istatistiksel olarak bir ilişki bulunmamıştır. Özyeterlilik ve problem çözme becerisi arasında pozitif yönde istatistiksel olarak anlamlı bir ilişki olduğu belirlenmiştir (Yenice, 2012; Altunçekiç, Yaman ve Koray, 2005) ve özyeterliğin, problem çözme başarısını tahmin etmede öğrencilerin genel akademik başarısını tahmin etmede olduğu gibi güçlü bir yordayıcı olduğunu belirtilmektedir (Pajares ve Kranzler,1995). Benzer olarak Chen (2002), özyeterlilik algısının problem çözme becerisi üzerinde pozitif bir etkisi olduğunu belirtmektedir. Özyeterlilik bağlamında yapılan araştırmalar bu çalışmada elde edilen sonucu desteklemektedirler.

\section{ÖNERILER}

Okul türüne göre problem çözmeye yönelik inançlar farklılaşmakta ve sonuçlar akademik yönden başarılı olan Fen Lisesi lehinedir. Düşük akademik başarıya sahip diğer liselerdeki öğrencilerin problem çözmeye yönelik inançlarını etkileyen değişkenlerin belirlenmesine yönelik araştırmalar yapılıp ögrencilerde olumlu inançların oluşması için gerekli çalışmalar yapılması faydalı olacaktır. Öğrencilerin akademik özyeterlik algıları ve problem çözmeye yönelik inançları arasında istatiksel olarak pozitif yönlü orta düzeyde bir ilişkinin tespit edilmesi sebebiyle, bu unsurlardan birinin güçlendirilmesine yönelik uygulamalarının diğerinin güçlenmesine de katkıda bulunabileceği göz önünde bulundurularak bu yönde yapılacak uygulamalarda bu iki kavramın birlikte ele alınması önerilebilir. Meslek lisesi öğrencilerinin akademik özyeterlik algılarının diğer lise türlerine göre düşük bulunması nedeniyle meslek lisesi öğrencilerine akademik özyeterlik inancının önemi kavratılmalı ve bu inanç düzeylerinin arttırılması yönünde çalışmalar yapılmalıdır. Meslek lisesi öğrencilerinin problem çözme inancı ve akademik özyeterlik algısının diğer lise türlerinden aşikar düzeyde farklılık göstermesi sebebiyle mevcut müfredattaki temel düzey matematik uygulamasıyla birlikte sınıf içi duyuşsal özellikleri destekleyecek etkinliklere de yer verilerek olumlu tutumların oluşması sağlanabilir.

\section{Bilgilendirme / Acknowledgement:}

1- Bu çalışma birinci yazarın, ikinci yazar danışmanlığında yaptığı yüksek lisans tez çalışmasından üretilmiştir.

2- Bu çalışma, X. Uluslararası Eğitim Araştırmaları Kongresinde poster olarak sunulmuştur.

3- Çalışmaya katkılarından dolayı akademisyen, öğretmen ve öğrencilere teşekkür ederiz 
4-Makalemizdeki veriler 2016-2017 Eğitim Öğretim Yılında toplanmış ve yorumlanmıştır.

5- Bu makalede araştırma ve yayın etiğine uyulmuştur.

\section{KAYNAKÇA}

Açık, S. (2013). Lise öğrencilerinin ögrenme stilleri ve problem çözme becerileri arasındaki ilişsinin incelenmesi. Yayımlanmamış yüksek lisans tezi, Abant İzzet Baysal Üniversitesi Eğitim Bilimleri Enstitüsü, Bolu.

Altunçekiç, A., Yaman, S., \& Koray, O. (2005). Öğretmen adaylarının öz-yeterlik inanç düzeyleri ve problem çözme becerileri üzerine bir araştırma (Kastamonu İli Örneği). Kastamonu Eğitim Dergisi, 13(1), 93-101.

Bandura, A. (1997). Self-efficacy: The exercise of control. New York: Freeman.

Bassarear, T. (1997). Mathematics for elementary school teacher. Boston: Houghton Mifflin .

Behjoo, B. (2013). The relationship among self-efficacy, academic self-efficacy, problem solving skills and foreign language achievement. Yayımlanmamış yüksek lisans tezi, Hacettepe Üniversitesi, Ankara.

Bıkmaz, F. (2004). Öz-yeterlik inançları. Y. Kuzgun, \& D. Deryakulu (Ed.) Eğitimde bireysel farklılıklar içinde. 289-308. Ankara: Nobel.

Bilgin, A. (2010). Üniversite öğrencilerinin çeşitli değişkenlere ve denetim odă̆ına göre problem çözme beceri algıları. Yayımlanmamış yüksek lisans tezi, Marmara Üniversitesi Eğitim Bilimleri Enstitüsü, İstanbul.

Byron, M. K. (1995). Confronting the verbal/visual issue: The mathematical problem-solving processes of a small group of female junior secondary students. Yayımlanmamıs doktora tezi, The Ohio State University, Ohio.

Callejo, M. L., \& Vila, A. (2009). Approach to mathematical problem solving and students' belief systems: two case studies. Educational Studies in Mathematics, (72), 111-126.

Chapman, O. (1997). Metaphors in the teaching of mathematical problem solving. Educational Studies in Mathematics, 32(3), 201-228.

Cribari, R. (2006). Socio-cultural factors and seventh grade students' attitudes and belief about mathematics. Yayımlanmamış doktora tezi, University of Northern Colorado, Colorado.

Develioğlu, M. (2006). Problem çözme becerileri yüksek ve düşük olan ögrrencilerin karar verme stratejilerinin bazı değişkenler açısından incelenmesi. Yayımlanmamış yüksek lisans tezi, Hacettepe Üniversitesi Sosyal Bilimler Enstitüsü, Ankara.

Erdem, E. (2006). Probleme dayalı ögrrenmenin ögrenme ürünlerine, problem çözme becerisine ve özyeterlik algı düzeyine etkisi. Yayımlanmamış doktora tezi, Hacettepe Üniversitesi Sosyal Bilimler Enstitüsü, Ankara.

Hacıömeroğlu, G. (2011,a). Sınıf öğretmeni adaylarının matematiksel problem çözmeye ilişkin inançlarını yordamada epistemolojik inançlarının incelenmesi. Buca Eğitim Fakültesi Dergisi, 30, 206-220. 
Hacıömeroğlu, G. (2011,b). Problem çözmeye ilişkin inanç ölçeğinin Türkçe'ye uyarlama çalışması. Dicle Üniversitesi Ziya Gökalp Eğitim Fakültesi Dergisi 17, 119-132.

Hackett, G., \& Betz, N. E. (1989). An exploration of the mathematics self efficacy/mathematics performance correpondence. Journal for Research in Mathematics Education, 20(3), 261-273.

House, J. D. (2006). Mathematics beliefs and achievement of elementary school students in Japan and the United States: results from the third international mathematics and science study. The Journal of Genetic Psychology, 167(1), 31-45.

Kayaaslan, A. (2006). Illköğretim 4. ve 5. sinıf öğrencilerinin matematiğin doğası ve matematik ögretimi hakkındaki inançları. Yayımlanmamış yüksek lisans tezi, Gazi Üniversitesi Eğitim Bilimleri Enstitüsü, Ankara.

Kemer, G. (2006). The role of self-efficacy, hope and anxiety in predicting university entrance examination scores of eleventh grade students. Yayımlanmamış yüksek lisans tezi, Orta Doğu Teknik Üniversitesi, Ankara.

Kiamanesh, A., Hejazi, E., \& Esfahani, Z. (2004). The role of math selfefficacy, math self-concept, perceived usefulness of mathematics and math anxiety in math achievement. Proceedings of the 3rd International Biennial SELF Research Conference SELF Research Conference, SelfConcept, Motivation and Identity: Where to from here? Berlin: Germany.

Kloosterman, P., \& Stage, F. K. (1992). Measuring beliefs about mathematical problem solving. School Science and Mathematics, 92(3), 109-115.

Korkut, F. (2002). Lise öğrencilerinin problem çözme becerileri. Hacettepe Üniversitesi Ĕgitim Fakültesi Dergisi, 22, 177-184.

Kumar, R., \& Lal, R. (2006). The role of self-efficacy ve gender difference among the adolescents. Journal of the Indian Academy of Applied Psychology, 32(3), 249-254.

Kurbanoğlu, N., \& Takunyac1, M. (2012). Lise öğrencilerinin matematik dersine yönelik kayg1, tutum ve öz-yeterlik inançları bazı değişkenlere göre incelenmesi. Uluslar arası Insan Bilimleri Dergisi, 9(1), 110-130.

Malpass, J. R., O’Neil, H. F., \& Hocevar, D. (1996). Self-regulation, goal orientation, self-efficacy and math achievement. NewYork: American Educational Research Association .

Mason, L., \& Scrivani, L. (2004). Enhancing students' mathematical beliefs: an intervention study. Learning and Instruction, 14, 153-176.

Mayer, R. E., \& Hegarty, M. (1996). The process of understanding mathematical problems.R. ,. Sternberg, \& T. Ben-Zeev (Ed.) The nature of mathematical thinkin içinde. 29-53. Mahwah, NJ: Lawrence Erlbaum.

McLeod, D. (1992). Research on affect in mathematics education: a reconceptualization. D. Grouwsm (Ed.). Handbook of research on mathematics teaching and learning içinde. 575-596. New York: Macmillan.

McLeod, D. B., \& McLeod, S. H. (2002). Synthesis - beliefs and Mathematics education: Implications for learning, teaching, and research. G. C. Leder, E. Pehkonen, \& G. Törner (Ed.). Beliefs: A Hidden Variable in Mathematics Education? Içinde. 115-127. Dordrecht: Kluwer Acedemic.

Milli Eğitim Bakanlığı Talim ve Terbiye Kurulu Başkanlığı (2013). Ortaöğretim matematik dersi ögretim programı. Ankara: MEB. 1 Ocak 2015 tarihinde http://mufredat.meb.gov.tr/: http://mufredat.meb.gov.tr/ProgramDetay.aspx?PID=343 adresinden erişildi.

National Council Of Teachers Of Mathematics. (1989). Curriculum and evaluation standards for school mathematics. Reston, VA: The Council. 
National Council Of Teachers Of Mathematics. (2000). curriculum and evaluation standards for school mathematics. Reston, VA: The Council.

National Council of Teachers of Mathematics. (2000). Principles and standards for school mathematics. Reston, VA: The Council.

Owen, S., \& Forman, R. D. (1988). Development of a college academic self efficacy scale. Annual Meeting of the National Council on Measurement in Education, New Orleans.

Özlü, Ö. (2001). Ortä̈gretim ögrencilerinin matematik dersine karşı tutumları. Yayımlanmamış yüksek lisans tezi, Marmara Üniversitesi Fen Bilimleri Enstitüsü, İstanbul.

Pajares, F., \& Kranzler, J. (1995). Competence and confidence in mathematics: The role of selfefficacy, self-concept, anxiety, and ability. Annual Meeting of the American Educational Research Association, San Francisco.

Polya, G. (1945). How to solve it: a new aspect of mathematical method. NJ: Princeton University.

Polya, G. (1962). Mathematical discovery: on understanding, teaching, and learning problem solving. New York: John Wiley.

Raymond, A. M. (1997). Inconsistency between a beginning elementary school teacher"s mathematics beliefs and teaching practices. Journal for Research in Mathematics Education, 28(6), 552575 .

Richardson, V. (1996). The role of attitudes and beliefs in learning to teach. J. Sikula (Ed.). Handbook of Research on Teacher Education içinde. 102-119. New York: Macmillan.

Schoenfeld, A. (1989). Teaching mathematical thinking and problem solving. L. B. Resnick, \& B. L. Klopfer, Toward the thinking curriculum: Current cognitive research içinde. 83-103. US:Yearbook of the American Society for Curriculum Develop.

Schoenfeld, A. H. (1985). Mathematical problem solving. Orlando, Florida: Academic .

Schunk, D. (2011). Öğrenme teorilerine eğitimsel bir baklş. (2.b.). (M. Şahin, Çev.). Ankara: Nobel.

Sezgin, M. (2013). Öğrencilerin matematiğe yönelik tutumlarının akademik özyeterlik algıları ve algıladıkları ögretmen davranışları açısından incelenmesi. Yayımlanmamış yüksek lisans tezi,, İstanbul Üniversitesi, İstanbul.

Yenilmez, K., \& Özabacı, N. Ş. (2003). Yatılı öğretmen okulu öğrencilerinin matematik ile ilgili tutumları ve matematik kaygı düzeyleri arasındaki ilişki üzerine bir araştırma. Pamukkale Üniversitesi Eğitim Fakültesi Dergisi, 2(14), 132-146.

Y1lmaz, K. (2007). Öğrencilerin epistemolojik ve matematik problemi çözümlerine yönelik inançlarının problem çözme sürecine etkisinin araştırılması. Yayımlanmamış yüksek lisans tezi, Marmara Üniversitesi, İstanbul.

Zimmerman, B. J. (1995). Self-efficacy and educational development. A. Bandura (Ed.). Self-efficacy in changing societies içinde. 202-231. New York: Cambridge University Press.

Zimmerman, B. J., \& Pons, M. M. (1986). Development of a structured interview for assessing student use of self-regulated learning strategies. .American Educational Research, 23(4), 614-628. 